\title{
TECTONOPHYSICS
}

ELSEVIER

Tectonophysics 341 (2001) 33-47

www.elsevier.com/locate/tecto

\section{Paleogeography and catchment evolution in a mobile orogenic belt: the Central Alps in Oligo-Miocene times}

\author{
Cornelia Spiegel*, Joachim Kuhlemann, István Dunkl, Wolfgang Frisch \\ Geologisches Institut, Universität Tübingen, Sigwartstr. 10, D-72076 Tübingen, Germany
}

Received 15 January 2001; accepted 20 July 2001

\begin{abstract}
In this study, we reconstruct the surface evolution of the Oligo-Miocene Central Alps using geochronological, geochemical and petrographical methods on the foreland basin sediments of both flanks of the mountain range. Our model is illustrated in four sketch maps of different time slices between mid-Oligocene to Middle Miocene times. For each time slice, we try to (1) give a palinspastic reconstruction of the Central Alps, based on the post-collisional lateral extrusion model, (2) show which tectonic units had become exposed to the surface due to exhumation processes in the Central Alps, (3) describe the thermochronologic evolution of lithological units formerly exposed but completely eroded today, (4) differentiate the catchment areas of the paleo-river systems which delivered debris to the foreland basins, and (5) describe the position of the main drainage divide relative to the exposed tectonic units. (C) 2001 Elsevier Science B.V. All rights reserved.
\end{abstract}

Keywords: Central Alps; Oligo-Miocene; Fission track; Drainage pattern; Exhumation

\section{Introduction}

Sediments of a foreland basin reflect the evolution of the adjacent orogen in the hinterland. For example, geochronological studies on detrital minerals give evidence of the thermal evolution and consequently of exhumation processes of the hinterland (see e.g. Wagner et al., 1979). Pebble sizes point to the paleorelief, and clast composition of conglomerates as well as heavy mineral fractions of sandstones reflect the lithologies exposed during the time of deposition. Petrographic and thermochronologic data from differ-

\footnotetext{
${ }^{*}$ Corresponding author. Tel.: +49-7071-2974-701; fax: +497071-5059.

E-mail address: cornelia.spiegel@uni-tuebingen.de (C. Spiegel).
}

ent dispersal systems of a foreland basin monitor changes of the drainage pattern, while comparing foreland basins of both flanks of an orogen may give information about the position of the main drainage divide. The masses of sediment in the foreland basins may reveal an estimate of the paleotopographic evolution (see e.g. Hay et al., 1992), though they cannot provide direct evidence for paleoaltitudes. Possibilities and errors of this approach are discussed in detail in Kuhlemann (2000) and Kuhlemann et al. (2001).

The aim of this study is to reconstruct the surface evolution and the drainage pattern of the Central Alps during Oligo-Miocene times by combining geochronological, geochemical and petrographical data from the northern and the southern foreland basins (Swiss molasse basin and Gonfolite Lombarda Group, respectively). In addition to the drainage pattern, we try 
to reconstruct and to differentiate exposed metamorphic domains of the hinterland during Oligo-Miocene times. Furthermore, our model attempts to incorporate the orogen-parallel lateral extrusion (Ratschbacher et al., 1991; Frisch et al., 1998), which decisively influenced the post-collisional surface evolution of the Alps. We present new thermochronological and geochemical data from sandstones and pebbles from the Swiss molasse basin and from sandstones of the Gonfolite Lombarda Group, whereas petrographic characterizations of the foreland basins and thermochronological data from pebbles of the Gonfolite Lombarda Group are compiled from the literature. Our results are illustrated in four sketch maps of different time slices. Estimations of the topographic evolution are based on the sediment accumulation curve of Kuhlemann (2000), which shows the sediment budget of the Central and the Western Alps since Oligocene times, separated for the north- and southdirected catchment.

\section{Geological setting of foreland and hinterland}

It is beyond the scope of this paper to give a detailed description of the geology of the Central Alps and the adjacent foreland basins. Our brief outline focuses on superimposed evolutionary trends. For more information, see e.g. Pfiffner (1986) and Matter and Weidmann (1992) for the Swiss molasse basin, Gunzenhauser (1985) and Gelati et al. (1988) for the Gonfolite Lombarda Group and Steck and Hunziker (1994) and Schmid et al. (1996) for the Central Alps.

\subsection{Swiss Molasse Basin}

Sedimentation in the Swiss molasse basin started in Oligocene times and lasted until $\sim 11 \mathrm{Ma}$ in the distal part of the basin (Pfiffner, 1986). The proximal part of the basin is composed of large fan systems containing conglomerates, sandstones and mudstones (Fig. 1). The sedimentary succession is characterised by two coarsening upward megacycles (e.g. Matter and Weidmann, 1992), indicating alternating shallow marine and alluvial conditions. Between 25-20 Ma, heavy mineral spectra of sandstones from different dispersal systems show an abrupt change from apatite/garnet towards epidote dominance (Füchtbauer, 1964; Schlunegger et al., 1997; Kempf et al., 1999). Most authors attribute this epidote dominance to the onset of erosion of South Penninic ophiolites in the Central Alps (Renz, 1937; Dietrich, 1969). Sedimentation ages of the Swiss molasse basin are well-constrained by biostratigraphic and magnetostratigraphic studies (Berger, 1992; Kempf et al., 1997; Schlunegger et al., 1997). Nomenclature and stratigraphy used in this study are according to Schlunegger et al. (1997) and Kempf (1998).

\subsection{Gonfolite Lombarda Group}

In contrast to the northern Alpine foreland basin, outcrops of Oligo-Miocene clastic sediments on the southern side of the Central Alps are restricted to the small area of the Gonfolite Lombarda Group (Fig. 1). The base of the Gonfolite Lombarda sensu lato is formed by the mainly pelitic Chiasso Formation, representing deep marine, turbiditic slope sediments (Gunzenhauser, 1985) with Rupelian to Early Chattian sedimentation ages (Gelati et al., 1988; Rögl et al., 1975). The overlying Chattian to Aquitanian Como Formation is mainly composed of conglomerates deposited in a submarine canyon system (Bernoulli et al., 1993). The youngest part of the Gonfolite Lombarda - the conglomerates of the Lucino Formation - is often referred to as Burdigalian to Langhian (e.g. Gunzenhauser, 1985). Based on palynological studies, Giger and Hurford (1989) suggest a Middle Miocene age. Therefore, in accordance with Giger (1991), an age of around $15 \mathrm{Ma}$ is taken for the Lucino Formation.

\subsection{Central Alps}

In the present-day Central Alps, three tectonic mega-units are exposed (Fig. 1): the Austroalpine upper plate represents the former northern margin of the Adriatic microplate. It was thrust over Penninic units which comprise both oceanic and continental crust. The Helvetic realm, as the lowermost megaunit, represents the European continent.

Austroalpine units are characterized by a Cretaceous metamorphic event with metamorphic ages between 145 and 90 Ma (Frank et al., 1987), including high pressure metamorphism and a thermal peak at 


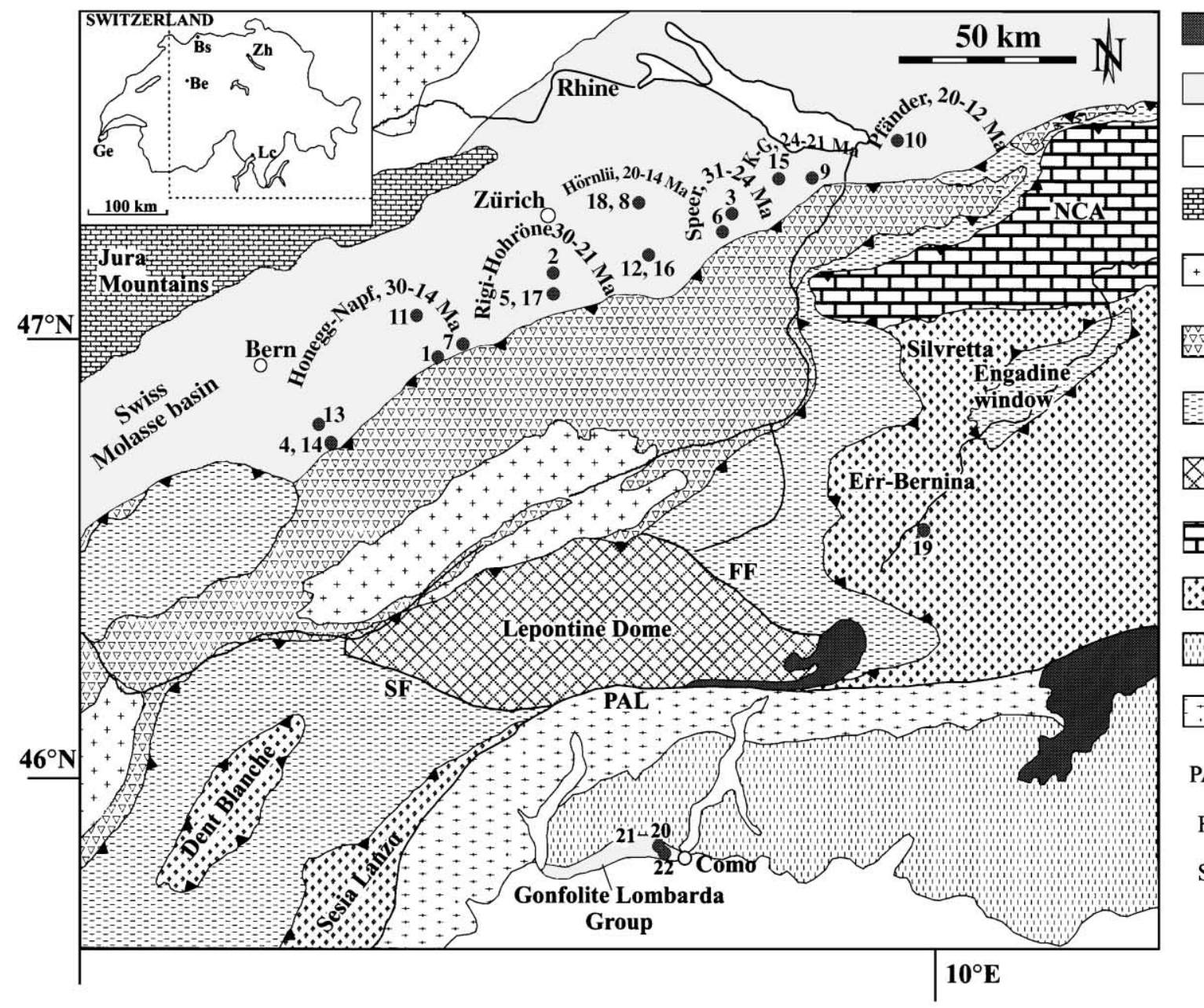

Periadriatic intrusions

Tertiary basins

Mesozoic foreland

Jura Mountains

European/Helvetic basement units

Helvetic cover units

\section{Other Penninic units} incl. Flysch nappes

Lower Penninic units of Lepontine Dome

Northern Calcareous Alps

(Austroalpine)

$\because \quad$ Other Austroalpine units

Southalpine

cover units

Southalpine basement

PAL Periadriatic lineament

FF Forcola fault

SF Simplon fault

Fig. 1. Geological sketch map of the Central Alps and the adjacent foreland basins. To the north, the Swiss molasse basin with its different dispersal systems with time of activity, and to the south, the Gonfolite Lombarda Group are shown. Numbers refer to localities of samples dated by the Zr FT method. K-G=Kronberg $-\mathrm{Gäbris} \mathrm{fan.} \mathrm{Inset:} \mathrm{Ge}=\mathrm{Geneva}$, Bs $=$ Basel, $\mathrm{Be}=$ Berne, $\mathrm{Zh}=$ Zurich, $\mathrm{Lc}=$ Lucerne . 
$\sim 90$ Ma (Thöni, 1981). Cooling ages <90 Ma are characteristic for amphibolite-facies units of the Austroalpine realm (Frank et al., 1987). Austroalpine units exposed in the western part of the Eastern Alps show a general decrease of Cretaceous metamorphic temperatures from amphibolite and eclogite facies conditions in the southeast, to temperatures below greenschist facies conditions in the northwestern parts of the Ötztal and the Silvretta block (e.g. Thöni, 1981). This zoning is reflected by the mineral cooling ages, becoming increasingly older towards the northwest with pre-Alpine cooling ages prevailing in the Silvretta block (Flisch, 1986). While Austroalpine units of the Eastern Alps, with few exceptions, were not affected by Tertiary metamorphism, Austroalpine units of the Western Alps (Dent Blanche Nappe, Sesia Lanzo Zone) have been thermally overprinted in Tertiary times as evidenced by Tertiary cooling ages (Hurford et al., 1991).

The structure of the Central Alps is dominated by the Lepontine Dome, which was metamorphosed during the Tertiary Lepontine metamorphism (Jäger, 1973; Steck and Hunziker, 1994). Its hanging wall consists of Upper to Middle Penninic units with South Penninic ophiolites at the top of the sequence (e.g. Platta unit). These ophiolites are considered as source rocks for the detrital epidote of the Swiss molasse basin (Renz, 1937; Dietrich, 1969). Rocks belonging to the hanging wall of the Lepontine Dome have zircon fission track (Zr FT) cooling ages between 30 and $15 \mathrm{Ma}$ (Hunziker et al., 1992) and a mid-Tertiary cooling rate in the range of $10{ }^{\circ} \mathrm{C} / \mathrm{Ma}$ (Markley et al., 1998). The Lepontine Dome, in contrast, consists of Lower Penninic units with frequent $\mathrm{Zr}$ FT cooling ages younger than $15 \mathrm{Ma}$ (Hunziker et al., 1992) and a mid-Tertiary cooling rate of up to $\sim 80{ }^{\circ} \mathrm{C} / \mathrm{Ma}$ (Hurford, 1986).

According to Meyre et al. (1998) and Frisch et al. (2000) the exhumation of the Lepontine Dome was mainly caused by the post-collisional lateral extrusion of the Alps. This extrusion period started around the Oligocene-Miocene boundary and led to an east-west stretching of the Central Alps of probably more than $100 \mathrm{~km}$ (Frisch et al., 2000). Two detachment faults bordering the Lepontine Dome have been attributed to the extension of the Central Alps: the Forcola fault to the east (active between ca. 25 and 18 Ma, Meyre et al., 1998) and the Simplon fault to the west (active between $19 \mathrm{Ma}$ and the present, Mancktelow, 1985).

\section{Dating of cooling ages in foreland basin sediments}

The concept of dating detrital minerals from foreland basins was proposed by Wagner et al. (1979) and others as a promising tool to unravel the thermal and dynamic evolution of an orogen. Cooling ages from synorogenic clastic sediments reflect age patterns of the hinterland at the time of sedimentation. This in turn allows a distinction between different tectonic units exposed during earlier stages of the orogen and gives information about their geodynamic behaviour. Details about the early metamorphic history are often obscured by later thermal events in the present-day exposures of the orogen but may be well-preserved in the foreland basin sediments. Comparing cooling ages from detrital minerals from different parts of a foreland basin and from both sides of an orogen gives evidence about the geological structure of individual catchment areas and about the positions of the drainage divides.

In general, three different approaches can be pursued in dating cooling ages on foreland basin sediments: (1) Dating detrital minerals from sandstones gives an overview of the ages contained in exposures over a whole catchment area (e.g. Brandon and Vance, 1992). (2) Dating different minerals from pebbles in foreland basin conglomerates provides paleo-cooling paths, and the pebbles themselves yield petrographic information about possible lithotectonic units in the source area (Wagner et al., 1979). (3) Pebble population dating was proposed by Dunkl et al. (1998). For this method, a large number of pebbles $(>50)$ of the same lithotype is collected from the same outcrop and processed together. The dating does not yield a single cooling age but an age distribution representing the whole lithological unit. A potential differential cooling behaviour of different lithological units can give additional information on the geodynamics in terms of exhumation in the hinterland.

All these approaches were pursued for the foreland basins of the Central Alps (Wagner et al., 1979; Giger and Hurford, 1989; Giger, 1991; von Eynatten et al., 1999; Spiegel et al., 2000). The mineral phases, according to the applied dating techniques, have different closure temperatures: ${ }^{40} \mathrm{Ar}-{ }^{39} \mathrm{Ar}$ and ${ }^{40} \mathrm{~K}-{ }^{40} \mathrm{Ar}$ on white mica: $350 \pm 50{ }^{\circ} \mathrm{C}$ (McDougall and Harrison, 1988; Purdy and Jäger, 1976), ${ }^{40} \mathrm{~K}-{ }^{40} \mathrm{Ar}$ on biotite: 
$300 \pm 50{ }^{\circ} \mathrm{C}$ (Armstrong et al., 1966), ${ }^{87} \mathrm{Rb}-{ }^{87} \mathrm{Sr}$ on biotite: $300 \pm 50{ }^{\circ} \mathrm{C}$ (Jäger et al., 1967), zircon fission track (Zr FT): $240 \pm 50{ }^{\circ} \mathrm{C}$ (Hurford, 1986) and apatite fission track: $120-60{ }^{\circ} \mathrm{C}$ (Wagner and Reimer, 1972). This temperature range allows to monitor thermal processes concerning approximately the upper $12 \mathrm{~km}$ of the earth's crust, assuming a geothermal gradient of $30{ }^{\circ} \mathrm{C} / \mathrm{km}$.

\section{Results and discussion: the paleogeographical evolution of the Central Alps on four sketch maps}

\subsection{Mid-Oligocene}

Fig. 2(a) shows the paleogeological situation of the Central Alps at the beginning of the coarse clastic molasse sedimentation in mid-Oligocene times. Because Tertiary large-scale lateral extrusion started around the Oligocene-Miocene boundary, i.e. 7-8 Ma later (Frisch et al., 2000), units today exposed in the Eastern and Western Alps (Ötztal and Silvretta block, Err-Berninia Nappe, Dent Blanche Nappe and Sesia-Lanzo Zone) were still situated in close neighbourhood. On the northern flank of the Central Alps, three large river systems delivered debris into the Swiss marine molasse basin: the Speer, Rigi-Hohröne and Honegg-Napf Rivers (Schlunegger et al., 1997; Kempf, 1998).

Zr FT age distributions from sandstones of these fans yield a typical Austroalpine pattern with a large range of Triassic, Jurassic and Cretaceous cooling ages. The badly constrained age groups around 50$40 \mathrm{Ma}$ of the Speer and the Rigi-Hohröne sandstones might be related to a volcanic event documented in the Penninic Schlieren flysch in the Swiss Alps (Winkler et al., 1990) or to the Eocene collision (see e.g. Schmid et al., 1996). The age distributions can be attributed to the recycling of flysch nappes, which in turn were fed from an Austroalpine source (Spiegel et al., 2000). The conglomerates of the Speer and Rigi-Hohröne fans contain exclusively flysch, limestone and dolomitic pebbles (Kempf, 1998; Schlunegger et al., 1998), whereas the Honegg-Napf fan additionally contains a small number of crystalline pebbles, mainly green granites (Schlunegger et al., 1998). Therefore, mainly sedimentary cover nappes and only few Austroalpine basement were exposed on the northern side of the Central Alps. The interpretation that a great part of the zircons contained in mid-Oligocene molasse strata are recycled Austroalpine zircon crystals from an intermediate flysch source is corroborated by the fact that in younger sediments, the ages become older (see Fig. 2(b)). Rivers incising into exposed crystalline basement should supply zircons with increasingly younger ages according to the prograding exhumation of rocks. This trend becomes inverted when crystals were stored in flysch in an intermediate stage. The Tertiary cooling ages from the Speer and RigiHohröne sandstones show that the exposed flysch was at least partly deposited during post-Cretaceous times.

On the southern flank of the Central Alps, Austroalpine basement as well as South Alpine basement and cover units were exposed (Giger, 1991). The Austroalpine basement was very probably affected by Alpine Cretaceous metamorphism, as indicated by some pebbles with Austroalpine provenance and Zr FT cooling ages between 60-55 Ma (Giger, 1991). However, because no geochronological data from sandstones is available for this time slice, a reliable description of the age pattern of Austroalpine basement exposed in the south-draining hinterland is not possible. The Periadriatic lineament was topped by a volcanic chain completely eroded today (Giger, 1991; Ruffini et al., 1997; Brügel, 1998; Frisch et al., 1998; Brügel et al., 2000). These volcanoes delivered volcanoclastic material to the Gonfolite Lombarda Group (Giger, 1991) and to many other Peri-Alpine sedimentary units, e.g. the Apennines, Lombardian flysch, the Austrian molasse basin, Slovenian basin fragments and the Pannonian basin (Dunkl et al., 2000). In contrast, no detrital zircons or pebbles related to the Periadriatic volcanism were deposited in the Swiss molasse basin.

The clast compositions of the conglomerates show that the main drainage divide must have been situated mainly north of the exposed Austroalpine basement during mid-Oligocene times. In the easternmost part of the Central Alps, the main drainage divide, however, jumped towards the south in order to give way to the large catchment area of the paleo-Inn river (Brügel, 1998; Brügel et al., 2000).

The sediment accumulation curve shows an increase of the sediment supply after $30 \mathrm{Ma}$ (Fig. $3)$. This increase and the onset of coarse clastic, 

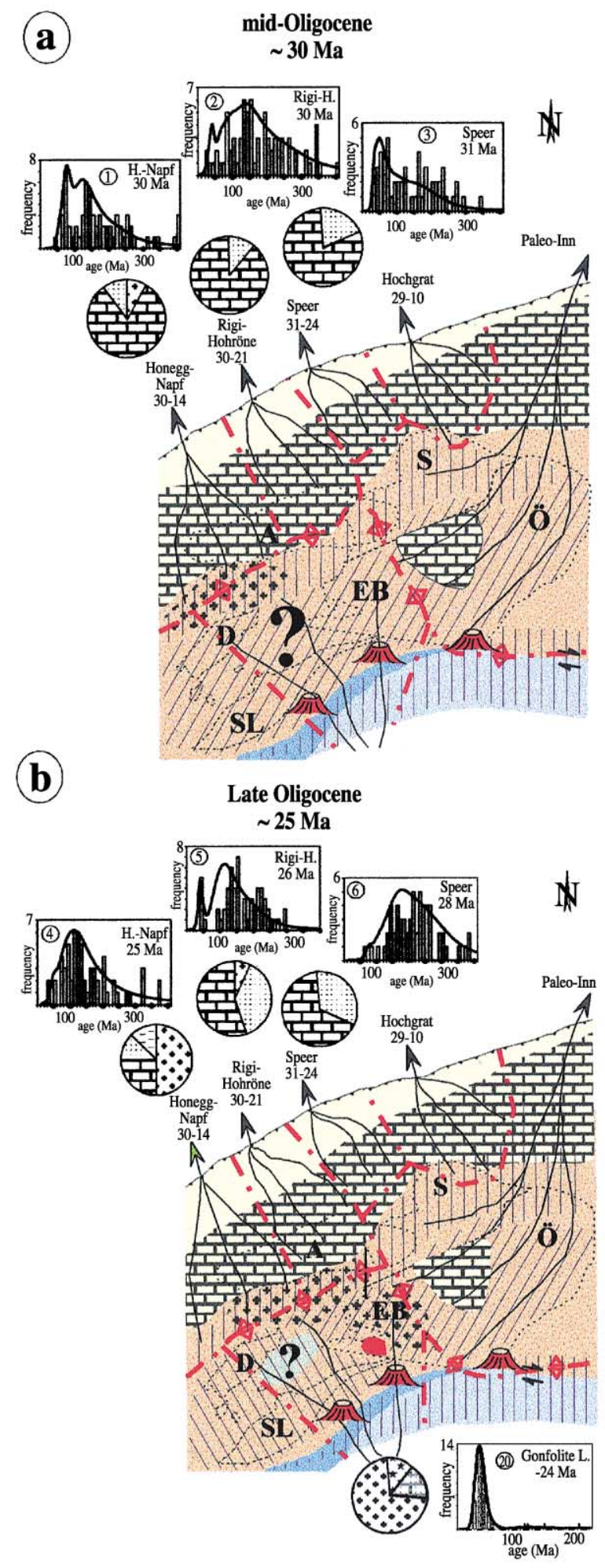

\section{Legend for the maps}

Periadriatic magmatic bodies

Southalpine a: sedimentary cover b: crystalline basement

a Sedimentary cover units in general (a:Flysch, b: limestone and dolomite)

- $\rightarrow$ Austroalpine units b: mainly granitic

(1.) Upper and Middle Penninic i.

Lower Penninic units (Lepontine Dome)

|||||| Region with mainly pre-Cretaceous metamorphism

I/// Region with mainly Cretaceous metamorphism $\left(\mathrm{T}>240^{\circ} \mathrm{C}\right)$

Region with mainly Tertiary metamorphism $\left(\mathrm{T}>240^{\circ} \mathrm{C}\right)$

\section{S Silvretta block \\ EB Err-Bernina unit \\ ö Ötztal block \\ A Aar-Massif \\ D Dent Blanche unit \\ SL Sesia Lanzo unit}

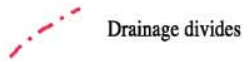

Main Alpine

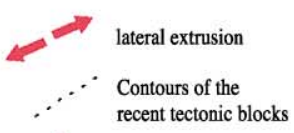

N

Epidote is the dominant heavy mineral

\section{Legend for the clast composition}

포돈 Limestone .::-:.:: Flysch

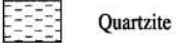

$\because \because \quad$ Crystalline rocks

$\square$ Sedimentary rocks in general

Tertiary magmatic rocks

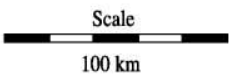


c)

Early Miocene

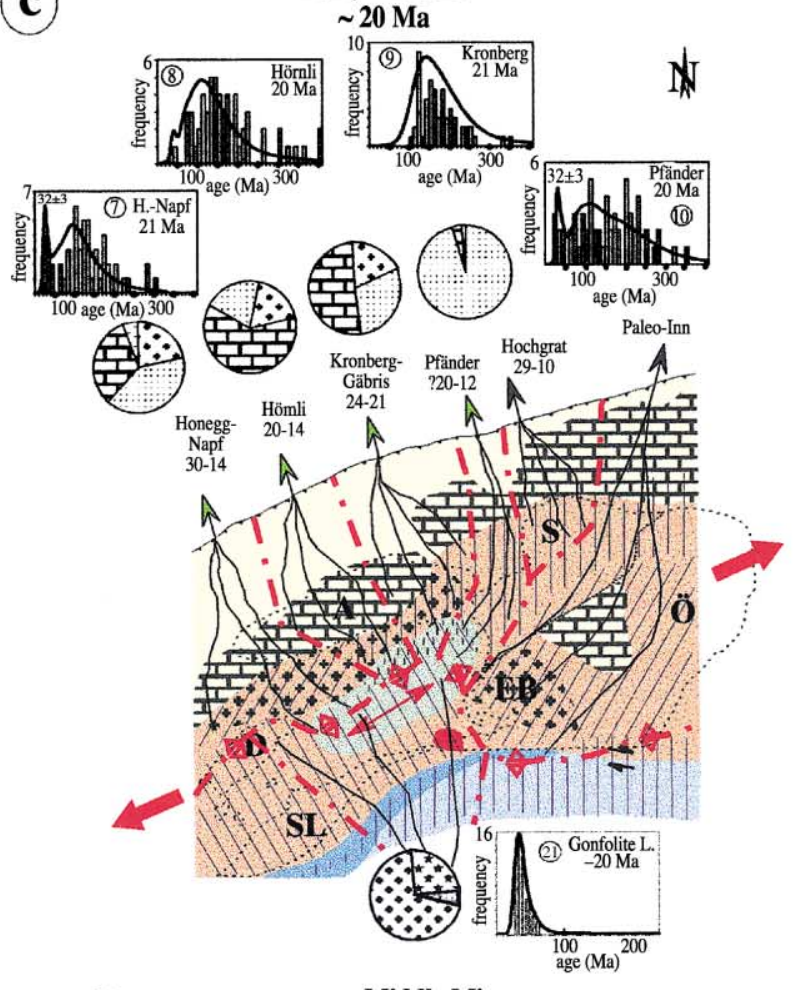

(d)

Middle Miocene

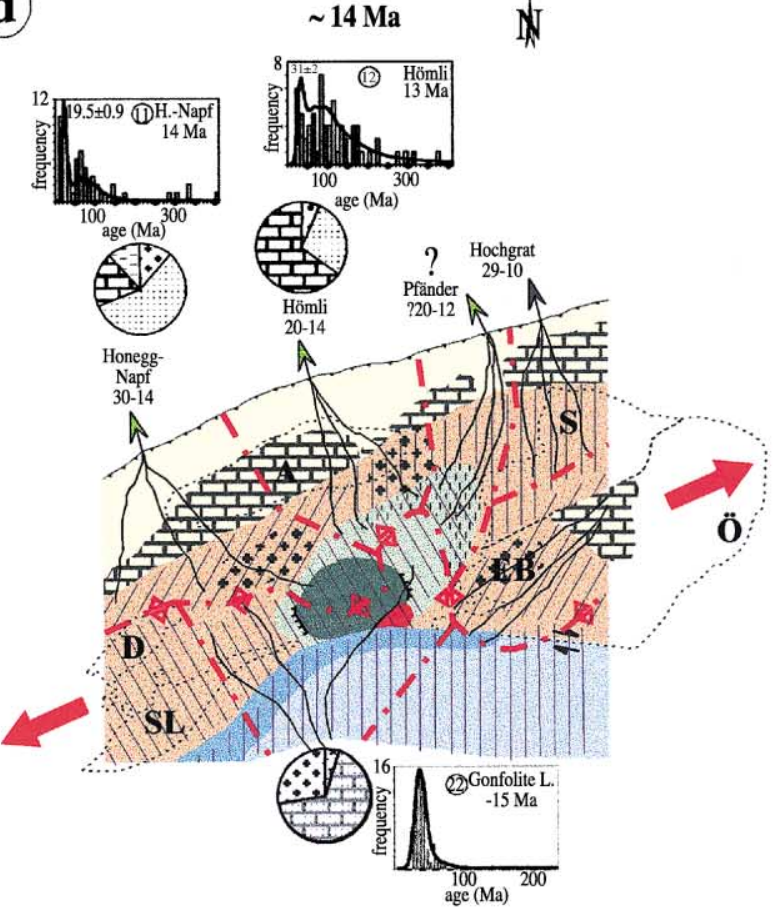




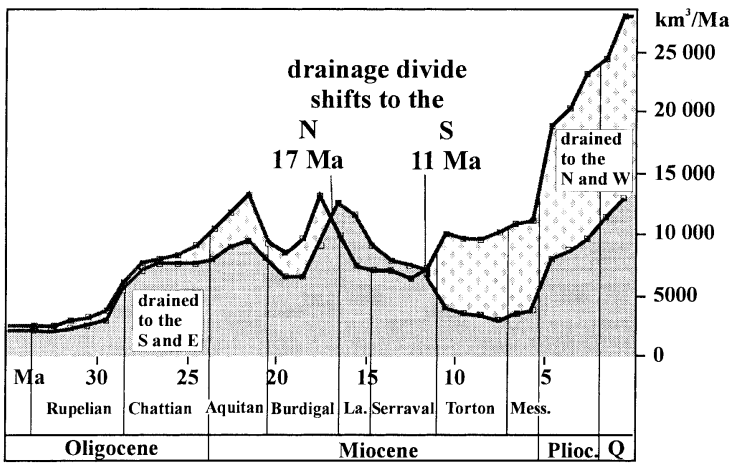

Fig. 3. Sediment budget since Oligocene times for the Central and Western Alps, separated for the north- and south-directed catchment after Kuhlemann (2000). A decrease of the sediment supply to the north at $17 \mathrm{Ma}$ is coupled with an increase of the sediment supply to the south and vice versa at $11 \mathrm{Ma}$. These antagonistic changes are interpreted as shifts of the main drainage divide to the north and to the south, respectively.

conglomerate-rich sedimentation in the foreland basins reflects the development of a significant relief in the hinterland.

\subsection{Late Oligocene (Fig. 2(b))}

The same river systems as described before were still active during Late Oligocene times (Schlunegger et al., 1997; Kempf, 1998). Sandstones from these rivers again show Zr FT age distributions typical for an Austroalpine source (Spiegel et al., 2000). In the Honegg-Napf fan, heavy mineral composition of the sandstones changed at $25 \mathrm{Ma}$ from apatite-garnet towards epidote dominance (up to $90 \%$ epidote, Schlunegger et al., 1997). While conglomerates of the Speer fan still comprised only pebbles from sedimentary cover nappes (Kempf, 1998), conglomerates of the Rigi-Hohröne fan contain some crystalline pebbles, mainly red granites (Schlunegger et al., 1998). These red granites also occur in the Honegg-Napf fan, as well as green and white granites, rhyolites and granitic gneisses. A prominent feature of the Honegg-Napf fan at $25 \mathrm{Ma}$ is the occurrence of green quartzites, which can make up as much as $10 \%$ of the conglomeratic components (Schlunegger et al., 1998).

According to Schlunegger et al. (1998) the Upper to Middle Penninic hanging wall of the Lepontine Dome became exposed at $25 \mathrm{Ma}$ in the north-draining part of the Central Alps. Their model is based on two assumptions: (i) the sudden occurrence of epidote in the sandstones of the Honegg-Napf fan indicates the onset of erosion of ophiolitic rocks from the top of the Penninic sequence; (ii) the green quartzite pebbles of the Honegg-Napf fan were derived from the Middle Penninic Bernhard nappe, which contains similar quartzites in terms of petrography in the present-day exposure. $\mathrm{Sr}$ and $\mathrm{Nd}$ isotopic ratios, however, reveals a crustalderived, granitic source rock for the detrital epidote (Spiegel et al., submitted). This indicates provenance from an Austroalpine source rock similar to the Lower Austroalpine metagranites as proposed by Füchtbauer (1964). Pebble population dating of the green quartzites yields a Zr FT cooling age of $111 \pm 5 \mathrm{Ma}$ (Table 1). The Middle Penninic nappes west of the Simplon line show Zr FT ages between $\sim 25$ and $20 \mathrm{Ma}$ (Seward and Mancktelow, 1994) and a cooling rate in the range of 10 ${ }^{\circ} \mathrm{C} / \mathrm{Ma}$ (Markley et al., 1998). Thus, a provenance of the green quartzitic pebbles from the Middle Penninic Bernhard nappe is not possible, i.e. neither the cooling age distribution or the heavy minerals of the sandstones nor the pebbles of the conglomerates point to an exposure of the Penninic hanging wall of the Lepontine Dome in the hinterland of the Swiss molasse basin in Oligocene times.

Based on petrographic criteria, the red and green granites of the molasse conglomerates have been

Fig. 2. Paleogeographic evolution of the Central Alps from mid-Oligocene times (a) to Middle Miocene times (d) with FT age distributions of detrital zircons from sandstones of the foreland basins and clast compositions of conglomerates. The probability density plots are computed according to Hurford et al. (1984), calculation of the young zircon age groups according to Brandon (1992), plotting by TRACKKEY (Dunkl, in press). Sedimentation ages of sandstones are at the right top corner; numbers in circles refer to sample localities (see Fig. 1). Nomenclature and stratigraphy of the Swiss molasse fans are according to Schlunegger et al. (1997) and Kempf (1998), stratigraphy of the Gonfolite Lombarda Group is after Gunzenhauser (1985), Rögl et al. (1975) and Giger and Hurford (1989). The Pfänder fan of the Austrian molasse basin is assumed to form an independent system only from ca. 20 Ma onwards (see Schiemenz, 1960). The drainage patterns of the Hochgrat and Paleo-Inn systems are modified after Brügel (1998) and Brügel et al. (2000). Clast compositions: Honegg-Napf and Rigi-Hohröne fan: Schlunegger et al. (1998), Kronberg-Gäbris and Speer fan: Kempf (1998) (with further references), Hörnli fan: Tanner (1944), Pfänder fan: Schiemenz (1960), Gonfolite Lombarda Group: Giger (1991), Longo (1968). 
Table 1

Results of zircon FT dating on sandstones and pebbles

\begin{tabular}{|c|c|c|c|c|c|c|c|c|c|c|c|c|}
\hline \multirow{2}{*}{$\begin{array}{l}\text { Sample } \\
\text { code }\end{array}$} & \multirow[t]{2}{*}{ Fan/location } & \multirow[t]{2}{*}{ Lithology } & \multirow{2}{*}{$\begin{array}{l}\text { Sedimentation } \\
\text { age }(\mathrm{Ma})\end{array}$} & \multirow{2}{*}{$\begin{array}{l}\text { Counted } \\
\text { crystals }\end{array}$} & \multicolumn{2}{|c|}{ Spontaneous } & \multicolumn{2}{|c|}{ Induced } & \multirow{2}{*}{$\begin{array}{l}P \chi^{2} \\
(\%)\end{array}$} & \multicolumn{2}{|c|}{ Dosimeter } & \multirow{2}{*}{$\begin{array}{l}\text { Central age } \\
(\mathrm{Ma} \pm 1 \sigma)\end{array}$} \\
\hline & & & & & $\rho_{\mathrm{s}}$ & $n_{\mathrm{s}}$ & $\rho_{\mathrm{i}}$ & $n_{\mathrm{i}}$ & & $\rho_{\mathrm{d}}$ & $n_{\mathrm{d}}$ & \\
\hline 22 & Gonfolite Lombarda & sandstone & $\sim 15$ & 59 & 131.2 & 4136 & 146.3 & 4624 & 0 & 6.31 & 12343 & $33.6 \pm 1.5$ \\
\hline 21 & Gonfolite Lombarda & sandstone & $\sim 20$ & 60 & 70.1 & 3622 & 83.3 & 4303 & 0 & 6.45 & 12377 & $32.2 \pm 1.2$ \\
\hline 20 & Gonfolite Lombarda & sandstone & $\sim 24$ & 53 & 143.9 & 4187 & 143.1 & 4163 & 0 & 6.51 & 12343 & $38.9 \pm 2$ \\
\hline 10 & Pfänder & sandstone & $\sim 20$ & 60 & 147.8 & 5903 & 42.3 & 1688 & 0 & 5.62 & 10784 & $119 \pm 11$ \\
\hline 19 & Bernina River & red granites PPD & recent & 20 & 349.8 & 2586 & 138.7 & 1025 & 24 & 4.75 & 8926 & $70 \pm 3$ \\
\hline 16 & Hörnli & red quartzite $\mathrm{PPD}^{\mathrm{a}}$ & 13 & 57 & 271.6 & 6804 & 53.2 & 1334 & 26 & 6.57 & 12343 & $193 \pm 7$ \\
\hline 18 & Hörnli & red granites $\mathrm{PPD}^{\mathrm{a}}$ & 20 & 47 & 248.8 & 4633 & 77.9 & 1450 & 9 & 6.45 & 12377 & $119 \pm 5$ \\
\hline 15 & Kronberg-Gäbris & granite SP & 24 & 25 & 284.2 & 3056 & 66.1 & 711 & 23 & 6.28 & 12343 & $155 \pm 7$ \\
\hline 14 & Honegg-Napf & quartzites PPD & 25 & 40 & 260.3 & 4223 & 55.7 & 903 & 21 & 4.1 & 8926 & $111 \pm 5$ \\
\hline 13 & Honegg-Napf & rhyolites $\mathrm{PPD}^{\mathrm{a}}$ & 26 & 63 & 262.7 & 6682 & 58.9 & 1498 & 6 & 6.45 & 12377 & $168 \pm 6$ \\
\hline 17 & Rigi-Hohröne & red granites $\mathrm{PPD}^{\mathrm{a}}$ & 27 & 25 & 245.9 & 3069 & 57.9 & 722 & 39 & 6.45 & 12377 & $158 \pm 7$ \\
\hline
\end{tabular}

$\mathrm{PPD}=$ dated according to the pebble population method (Dunkl et al., 1998), $\mathrm{SP}=$ single pebble dating. $n=$ number of counted tracks, $\rho=$ track densities $\left(\times 10^{5}\right.$ tracks $\left./ \mathrm{cm}^{2}\right), P\left(\chi^{2}\right)$ is the probability of obtaining $\chi^{2}$ value for $v$ degrees of freedom (where $v=$ number of crystals -1 ). Ages are calculated using dosimeter glasses $\mathrm{CN}-2$ with $\zeta \mathrm{CN}-2=116 \pm 2$. Dating was performed according to the external detector method (Fleischer et al., 1964). Samples 19 and 14 were irradiated at the ANSTO reactor, Lucas Heights (Australia), the other samples were irradiated at the thermal neutron facility of the Riso reactor (Denmark).

${ }^{\text {a }}$ Data from Spiegel et al. (2000).

attributed to a western prolongation of the granites exposed in the present-day Err-Bernina region (Matter, 1964). These granites belong to a calc-alkaline suite. They were intruded during Variscan orogeny and were overprinted in Triassic times (Jäger, 1973; Hunziker et al., 1992) and during Cretaceous Eoalpine metamorphism (Rageth, 1984; Spillmann and Büchi, 1993). Geochemically, they are characterized by low $\mathrm{Ti}, \mathrm{Sr}$ and $\mathrm{Ba}$, and high $\mathrm{Rb}$ contents (Rageth, 1984). In this study, we compared geochemistry and $\mathrm{Zr}$ FT cooling ages of red and green granitic pebbles from different molasse fans with petrographically similar pebbles from the recent Bernina river near St. Moritz (Fig. 1 and Tables 1 and 2). This river drains the Lower Austroalpine Err-Bernina region. Especially the red granites reveal similar geochemical characteristics for recent and molasse pebbles (Fig. 4). This corroborates the provenance of the granitic molasse pebbles from a western prolongation of the Err-Bernina granites, which is completely eroded today.

A pebble population of recent red granitic pebbles derived from the Bernina region reveals a $\mathrm{Zr}$ FT age of $70 \pm 3$ Ma (Table 1), reflecting cooling after the

Table 2

Geochemical analysis of granitic pebbles from the molasse basin and from the recent Bernina river

\begin{tabular}{|c|c|c|c|c|c|c|c|c|c|c|c|c|c|c|c|}
\hline Code & Lithology & Fan/river & $\begin{array}{l}\text { Sedimentation } \\
\text { age }(\mathrm{Ma})\end{array}$ & $\begin{array}{l}\mathrm{K}_{2} \mathrm{O} \\
\text { weight (\%) }\end{array}$ & $\begin{array}{l}\mathrm{Rb} \\
(\mathrm{ppm})\end{array}$ & $\begin{array}{l}\mathrm{Ba} \\
(\mathrm{ppm})\end{array}$ & $\begin{array}{l}\text { Th } \\
\text { (ppm) }\end{array}$ & $\begin{array}{l}\mathrm{Ta} \\
\text { (ppm) }\end{array}$ & $\begin{array}{l}\mathrm{Nb} \\
(\mathrm{ppm})\end{array}$ & $\begin{array}{l}\mathrm{Ce} \\
(\mathrm{ppm})\end{array}$ & $\begin{array}{l}\mathrm{Hf} \\
(\mathrm{ppm})\end{array}$ & $\begin{array}{l}\mathrm{Zr} \\
(\mathrm{ppm})\end{array}$ & $\begin{array}{l}\mathrm{Sm} \\
(\mathrm{ppm})\end{array}$ & $\begin{array}{l}\text { Y } \\
(\mathrm{ppm})\end{array}$ & $\begin{array}{l}\mathrm{Yb} \\
(\mathrm{ppm})\end{array}$ \\
\hline GC3 1 & red $g$ & sse & 21 & 4.75 & 403.8 & 23 & 38.83 & 3.60 & 29.61 & 32.01 & 5.82 & 105 & 5.55 & 47.62 & 5.69 \\
\hline GC4 1 & red granite & Hörnli & 13 & 5.32 & 233.6 & 149 & 31.18 & 3.07 & 10.17 & 42.87 & 3.91 & 84 & 6.50 & 41.63 & 4.47 \\
\hline GC6 1 & red granite & Bernina & recent & 4.95 & 289.5 & 52 & 29.58 & 13.64 & 32.88 & 55.39 & 7.35 & 169 & 11.51 & 86.46 & 6.67 \\
\hline GC7 1 & red granite & Bernina & recent & 4.52 & 323.1 & 16 & 32.22 & 3.38 & 36.55 & 53.87 & 7.87 & 164 & 9.87 & 81.72 & 7.79 \\
\hline $\mathrm{GC} 16$ & green granite & K.G. & 21 & 1.18 & 40.1 & 232 & 4.66 & 0.69 & 12.09 & 47.16 & 11.04 & 462 & 5.20 & 24.56 & 2.18 \\
\hline $\mathrm{GC} 18$ & green granite & K.G. & 21 & 3.83 & 155.8 & 343 & 13.27 & 2.05 & 14.71 & 35.26 & 3.86 & 131 & 3.70 & 25.67 & 2.48 \\
\hline GC19 & green granite & Hörnli & 20 & 4.85 & 206.1 & 160 & 21.47 & 1.83 & 18.24 & 60.17 & 6.44 & 200 & 7.04 & 38.60 & 3.96 \\
\hline $\mathrm{GC} 8$ & green granite & Bernina & recent & 3.12 & 104.5 & 431 & 17.19 & 1.22 & 10.85 & 73.92 & 4.20 & 145 & 5.15 & 19.34 & 1.80 \\
\hline GC9 & green granite & Bernina & recent & 3.69 & 146.0 & 468 & 11.90 & 1.33 & 10.96 & 46.85 & 4.33 & 147 & 4.59 & 24.61 & 2.34 \\
\hline GC10 & green granite & Bernina & recent & 5.10 & 257.9 & 463 & 7.86 & 1.37 & 12.53 & 45.84 & 11.67 & 485 & 4.60 & 27.91 & 3.72 \\
\hline
\end{tabular}



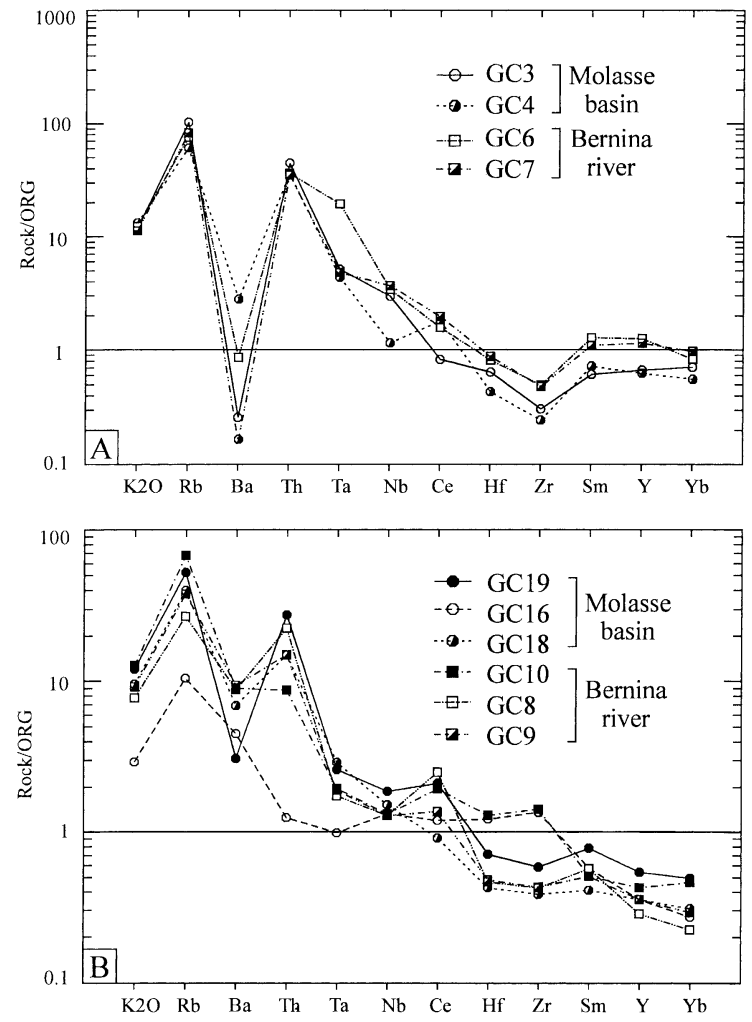

Fig. 4. Ocean ridge granite normalized (ORG, see Pearce et al., 1984) geochemical patterns for granitic pebbles from different fan systems of the Swiss molasse basin (circles) and from the recent Bernina river, draining the Lower Austroalpine Err-Bernina region (boxes). 3a: green granitic pebbles, 3b: red granitic pebbles. See also Table 2.

thermal peak of Cretaceous metamorphism at $\sim 90$ Ma (Thöni, 1981). In contrast, two pebble populations of red granites from the molasse basin yield $\mathrm{Zr}$ FT ages of $119 \pm 5$ and $158 \pm 7 \mathrm{Ma}$, similar to the ages of other pebble populations and single pebbles from the molasse conglomerates, which show exclusively Jurassic to Early Cretaceous Zr FT ages (Table 1). This age distribution is in line with the increasing temperatures of Cretaceous metamorphism from northwest to southeast, as is known from the Austroalpine Ötztal and Silvretta blocks (Thöni, 1981) when we assume continuous backward incision of the rivers towards the southeast. It also shows that the Cretaceous metamorphic gradient can be traced towards the west as the direct continuation of the Ötztal-Silvretta. This is corroborated by the exclusively Late Variscan to Jurassic ${ }^{40} \mathrm{~K}-{ }^{40} \mathrm{Ar}$ ages of white mica and biotite from pebbles of the molasse conglomerates (Spiegel et al., 2000) and by the absence of Cretaceous ${ }^{40} \mathrm{Ar}-{ }^{39} \mathrm{Ar}$ ages of detrital white mica from the molasse sandstones (von Eynatten et al., 1999). In conclusion, the eroded part of the Austroalpine basement in the Central Alps consisted of large areas, which experienced only weak or even no Eo-Alpine metamorphic overprint.

Zr FT age distributions of sandstones from the Gonfolite Lombarda Group reveal a different situation for the southern flank of the Central Alps. While $\mathrm{Zr}$ FT age spectra from the northern foreland show a heterogeneous distribution with predominantly Triassic, Jurassic and Cretaceous ages, sandstones from the southern foreland yield a very homogeneous distribution with a large majority of Zr FT ages clustering between 40 and $30 \mathrm{Ma}$ (Fig. 2(b)). The few Zr FT ages $>100 \mathrm{Ma}$ are presumably derived from the Variscan basement of the Southern Alps, whereas for the ages between 40 and $30 \mathrm{Ma}$, three potential sources can be considered: (1) the Periadriatic magmatic bodies, i.e. the Bergell pluton and volcanoes of the Periadriatic volcanic chain; (2) Austroalpine basement thermally overprinted during Tertiary Lepontine metamorphism; (3) Penninic rocks from the hanging wall of the Lepontine Dome.

(1) The erosion of Periadriatic magmatic rocks is proven by frequent tonalitic pebbles derived from the Bergell pluton in Late Oligocene conglomerates of the Gonfolite Lombarda Group (Wagner et al., 1979; Giger and Hurford, 1989; Giger, 1991). (2) According to Giger (1991), pebbles with Austroalpine provenance have Late Variscan to Triassic biotite ${ }^{40} \mathrm{~K}-{ }^{40} \mathrm{Ar}$ ages, Zr FT ages mainly between 38 and $33 \mathrm{Ma}$, while only a few pebbles yield Zr FT ages between 60 and 55 Ma (Giger, 1991). Thus, temperatures of Cretaceous metamorphism affecting the hinterland of the Gonfolite Lombarda Group probably were high enough to completely reset the Zr FT system (i.e. $>200-250{ }^{\circ} \mathrm{C}$ ) but too low to reset the biotite ${ }^{40} \mathrm{~K}-{ }^{40} \mathrm{Ar}$ ages (i.e. $<300{ }^{\circ} \mathrm{C}$ ). $\mathrm{Zr}$ FT ages of Austroalpine basement exposed on the northern flank of the Central Alps, in contrast, were only partly reset by Cretaceous metamorphism and unaffected by Tertiary metamorphism. (3) At $\sim 24 \mathrm{Ma}$, gneiss pebbles with biotite ${ }^{40} \mathrm{~K}-{ }^{40} \mathrm{Ar}$ ages and zircon and apatite fission track ages between $40-30 \mathrm{Ma}$ occurred in the con- 
glomerates of the Gonfolite Lombarda Group (Giger, 1991). Due to the high cooling rate and the young biotite ${ }^{40} \mathrm{~K}-{ }^{40} \mathrm{Ar}$ ages, Giger (1991) attribute these gneiss pebbles to the erosion of the Penninic hanging wall of the Lepontine Dome. Austroalpine basement from the direct contact to the Bergell plutonic body, however, might show the same cooling pattern. In conclusion, it is clear, that Periadriatic magmatitic bodies and Austroalpine basement affected by Tertiary metamorphism largely contributed to the sediments of the Gonfolite Lombarda Group in Late Oligocene times. A Penninic gneiss contribution would also be in line with the geochronological data but cannot ultimately be proven.

The borderline between Austroalpine basement affected and unaffected by Tertiary thermal overprint must have roughly coincided with the main drainage divide, which was situated within the exposed Austroalpine units.

The sediment supply in the molasse basins continuously increased during Chattian and also during Aquitanian times, suggesting a continuously rising relief of the Central Alps (Kuhlemann, 2000, Fig. 3 ). This is in line with the data of Hay et al. (1992). Absolute elevations of 5000-7000 $\mathrm{m}$ in Late Oligocene times as proposed by Jäger and Hantke (1984) and by Hay et al. (1992), however, seem to be unlikely.

\subsection{Early Miocene (Fig. 2(c))}

The Oligo-Miocene boundary approximately marks the onset of lateral extrusion, which led to an east-west stretching in the range of $170 \mathrm{~km}$ for the Eastern Alps (Frisch et al., 1998) and of $\sim 100 \mathrm{~km}$ for the Central Alps (Frisch et al., 2000), causing the tectonic denudation of the Tauern window and the Lepontine Dome. The enhanced exhumation of the hinterland should be reflected in the foreland basin sediments.

In the Swiss molasse basin, sediment discharge from the Speer and Rigi-Hohröne river systems ceased, and the Kronberg-Gäbris and Hörnli river systems became dominant (Schlunegger et al., 1997; Kempf, 1998). To the west, the Honegg-Napf river system persisted. For this time slice, zircons from sandstones of the Pfänder fan east of Lake Constance were also dated by the FT method (Table 1). The
Pfänder became an independent fan system only in Burdigalian times (Schiemenz, 1960). Conglomerates of all fans comprise crystalline pebbles in various amounts and sandstones of all fans contain epidote as the dominant heavy mineral.

$\mathrm{Sr}$ and $\mathrm{Nd}$ isotopic ratios of these epidotes point to a mantle-derived, basic source rock in all fan systems for the majority of the epidote (Spiegel et al., submitted). Therefore, we conclude that in Lower Miocene times, ophiolitic rocks from the very top of the Penninic nappe system became exposed over large areas of the Central Alps. These ophiolitic rocks were void of zircon, therefore, their erosion is not monitored by FT dating on detrital zircons from the foreland basin. This explains the Austroalpine age distribution of the Hörnli and Kronberg-Gäbris fan. In contrast, a $\sim 30 \mathrm{Ma} \mathrm{Zr}$ FT age group appears in the age spectra of the Honegg-Napf and Pfänder fans. Zircons of this age can be derived either from Penninic nappes of the Lepontine area or from Periadriatic magmatic bodies. The majority of the young zircon crystals in the sediment are relatively small, rounded and rose-coloured, unlike those zircons derived from Periadriatic magmatitic bodies, which are mainly euhedral, clear and colourless (see Dunkl et al., 2000). We therefore conclude that the young zircon grains were derived from Penninic units of the Lepontine area underlying the ophiolitic rocks. This indicates that (i) the Honegg-Napf and the Pfänder system rooted in deeper structural levels than the other fans of the Swiss molasse basin and (ii) the Pfänder system must have had a rather narrow catchment area reaching far to the southwest, similar to the present Rhine river catchment.

On the southern flank of the Central Alps, Periadriatic magmatitic bodies, Penninic nappes, South Alpine basement and cover units, and Austroalpine units displaying Tertiary metamorphism were all exposed (Giger, 1991). This is reflected by the according pebble lithologies (Giger, 1991) and by a sandstone Zr FT age spectrum with ages clustering mainly between $40-30 \mathrm{Ma}$ (Table 1). The number of South Alpine sedimentary pebbles increased, as compared to Late Oligocene times (Longo, 1968; Giger, 1991).

The main drainage divide was situated in the area of the Penninic units of the Lepontine region, but was still located north of the Periadriatic magmatic bodies, 
since no zircons typical for Periadriatic intrusives occur in sandstones of the northern foreland basin.

Contemporaneously with the exposure of Upper to Middle Penninic units over large areas of the Central Alps (ca. $21 \mathrm{Ma}$ ), the sediment supply in the foreland basins was greatly reduced (Hay et al., 1992; Kuhlemann, 2000). This decrease of the sediment discharge indicates the collapse of the relief due to large-scale lateral extrusion processes.

\subsection{Middle Miocene (Fig. 2(d))}

In Middle Miocene times $(\sim 14 \mathrm{Ma})$, the Central Alps had nearly reached their present east-west extension (Frisch et al., 2000). Only the HoneggNapf and the Hörnli river systems were still active, whereas sediment discharge from the KronbergGäbris system into the Swiss molasse basin had ceased (Schlunegger et al., 1997; Kempf, 1998).

In sandstones of the Hörnli fan, a $\sim 31 \mathrm{Ma}$ Zr FT age group appears, indicating that zircon-rich lithologies of the Penninic hanging wall of the Lepontine Dome had become exposed in the catchment area. In sandstones of the Honegg-Napf fan, a prominent $\mathrm{Zr}$ FT age group of $\sim 20$ Ma points to an average cooling rate of $\sim 40{ }^{\circ} \mathrm{C} / \mathrm{Ma}$ in the source region for Middle Miocene times (Spiegel et al., 2000), assuming a Zr FT closure temperature of $\sim 240{ }^{\circ} \mathrm{C}$ (Hurford, 1986). This cooling rate is too high to have its source in the hanging wall of the Lepontine Dome. Therefore, we conclude that in Middle Miocene times, the Lepontine Dome itself became exposed for the first time. At the same time the Penninic units of the Tauern window became exposed in the Eastern Alps (Brügel, 1998; Frisch et al., 1998). Both metamorphic domes of the Central and Eastern Alps were thus contemporaneously exhumed to the surface.

Conglomerates of the Honegg-Napf fan show a distinct increase of flysch pebbles as compared to Oligocene and Lower Miocene conglomerates (Schlunegger et al., 1998). According to Schlunegger et al. (1998) this is due to enhanced erosional denudation in the area of the Penninic and ultrahelvetic flysch nappes caused by a northward shift of the main drainage divide. Kuhlemann et al. (2001) also describe a shift of the main drainage divide towards the north at $17 \mathrm{Ma}$, based on an antagonistic change of the sediment budget on the opposite flanks of the Alps (Fig. 3).
However, the Zr FT data from the sandstones of the Honegg-Napf system suggest the exposure of Lower Penninic units from the Lepontine Dome in the catchment area. Therefore, the main drainage divide must at least locally have reached into the area of the Lepontine Dome, i.e. relatively far to the south. The increase of flysch pebbles in the conglomerates of the Honegg-Napf fan can also be explained by the uplift of the Aar massif during Miocene times (Michalski and Soom, 1990), which caused an enhanced erosion of tectonic units on top of it, including large flysch nappes.

In the southern foreland basin, the conglomerates of the Lucino Formation as the youngest part of the Gonfolite Lombarda Group were deposited at $\sim 15$ Ma (Giger and Hurford, 1989). Compared to Early Miocene conglomerates, they show an increase of sedimentary pebbles with South Alpine provenance (up to $67 \%$, Longo, 1968), reflecting the enhanced uplift of the Southern Alps. Moreover, South Alpine and Austroalpine basement, as well as Penninic units and Periadriatic intrusives were exposed in the southdraining part of the Central Alps (Giger, 1991). According to Giger (1991), the Lucino Formation contains pebbles which are similar to gneisses from the Lower Penninic Lepontine Dome in terms of petrography. No Zr FT ages are available from these pebbles. ${ }^{40} \mathrm{~K}-{ }^{40} \mathrm{Ar}$ ages on biotite, however, are in the same range as ${ }^{40} \mathrm{~K}-{ }^{40} \mathrm{Ar}$ ages from pebbles which are interpreted to have been sourced from higher levels of the Penninic nappe pile ( 24-28 Ma, Giger, 1991). The exposure of the Lepontine Dome in the catchment area of the Gonfolite Lombarda Group should be reflected by a shift of the FT age distribution of detrital zircon towards younger cooling ages. No such shift occurred in the Zr FT age spectra of sandstones from the Lucino Formation (Fig. 2(d)), as compared to sandstones with Early Miocene sedimentation age (Fig. 2(c)). Because of the northward shift of the main drainage divide at $17 \mathrm{Ma}$, it seems unlikely that the whole exposure of the Lepontine Dome was drained towards the north in Middle Miocene times. We therefore conclude that the Lepontine Dome was not exposed during the time of deposition of the Lucino Formation. This implies either a sedimentation age older than $15 \mathrm{Ma}$ for the Lucino Formation, or the first exposure of the Lepontine Dome can in fact be bracketed very precisely between 15 and $14 \mathrm{Ma}$. 
After a short-lived enhancement in the course of updoming of the Lepontine core complex at around 17 Ma (Kuhlemann, 2000), the sediment supply has dropped again and persisted at the same level throughout Middle Miocene times (Fig. 3). The sediment accumulation data suggests that the relief of the Central Alps was greatly enhanced during Plio-Pleistocene times, reaching a maximum relief at the present time.

\section{Conclusions}

\subsection{Paleogeography and surface evolution}

In Mid-Oligocene times, the northern flank of the Central Alps was dominated by sedimentary cover nappes with only minor exposures of Austroalpine basement. To the south, a volcanic chain was situated in the region of the Periadriatic lineament. In Late Oligocene times, still only sedimentary cover units and Austroalpine basement were exposed on the north-draining side of the Central Alps, whereas rocks of the underlying Penninic mega-unit may have become exposed on the south-draining side. The post-collisional lateral extrusion of the Alps started around the Oligocene-Miocene boundary, causing the collapse of the relief and the exposure of Upper to Middle Penninic units over large areas of the Central Alps at 21-20 Ma. Finally, in Middle Miocene times, the Lower Penninic Lepontine Dome was exhumed to the surface, contemporaneously with the opening of the Tauern window in the Eastern Alps.

\subsection{Metamorphism and thermal evolution}

Austroalpine basement exposed during OligoMiocene times on the northern side of the Central Alps underwent temperatures $\leq 240{ }^{\circ} \mathrm{C}$ during Cretaceous metamorphism. The temperature pattern with a distinct gradient known from the Ötztal-Silvretta block was continuous towards the west, suggesting that the formerly exposed Austroalpine basement was the direct western prolongation of the Ötztal-Silvretta block. According to geochronological data, Cretaceous metamorphic temperatures in the Austroalpine basement exposed in the south-draining part of the Central Alps were slightly higher than in the north but still below $\sim 300{ }^{\circ} \mathrm{C}$. Tertiary Lepontine metamorphism did not affect the Austroalpine basement of the northern flank, but reached temperatures between $\sim 240$ and $300{ }^{\circ} \mathrm{C}$ on the southern flank.

\subsection{Catchment areas and drainage pattern}

Between 30-20 Ma the main drainage divide of the Central Alps migrated towards the south. Sedimentological studies imply a northward shift at $17 \mathrm{Ma}$ (Kuhlemann et al., 2001), but despite this, the main water divide was still situated within the Lower Penninic basement nappes of the Lepontine Dome, as proved by geochronological data (von Eynatten et al., 1999; Spiegel et al., 2000).

Of all dispersal systems of the Swiss molasse basin, the Honegg-Napf fan in the western part of the basin rooted into the deepest tectonic units. It was the first fan to receive young zircons with Penninic provenance and the only fan that received debris from the Lower Penninic units of the Lepontine Dome. The headwaters of the Pfänder system of the western Austrian molasse basin also rooted in Penninic units of the Central Alps, indicating a southwest-elongated catchment area similar to the present Rhine river. The Pfänder system might therefore be called 'PaleoRhine.'

\section{Acknowledgements}

This study was financed by the German Science Foundation in the frame of the Collaborative Research Centre SFB 275. Geochemical analysis were carried out by Diane Johnson and Charles Knaack (GeoAnalytical Lab, Washington State University). Reviews by Lothar Ratschbacher, Jean-Pierre Burg and an anonymous reviewer improved an earlier version of this paper. All support is gratefully acknowledged.

\section{References}

Armstrong, R., Jäger, E., Eberhardt, P., 1966. A comparison of ${ }^{40} \mathrm{~K}-{ }^{40} \mathrm{Ar}$ and $\mathrm{Rb}-\mathrm{Sr}$ ages on Alpine biotites. Earth Planet. Sci. Lett. 1, 13-19.

Berger, J.-P., 1992. Correlative chart of the European Oligocene and Miocene: application to the Swiss Molasse Bassin. Eclogae Geol. Helv. 85, 573-609.

Bernoulli, D., Giger, M., Mueller, D., Ziegler, U., 1993. Sr-isotope- 
stratigraphy of the Gonfolite Lombarda Group (South-Alpine Molasse, northern Italy) and radiometric constraints for its age of deposition. Eclogae Geol. Helv. 86, 751-767.

Brandon, M.T., 1992. Decomposition of fission-track grain-age distributions. Am. J. Sci. 292, 535-564.

Brandon, M.T., Vance, J.A., 1992. Fission-track ages of detrital zircon grains: implications for the tectonic evolution of the Cenozoic Olympic subduction complex. Am. J. Sci. 292, 565-636.

Brügel, A., 1998. Provenances of alluvial conglomerates from the Eastalpine foreland: Oligo-Miocene denudation history and drainage evolution of the Eastern Alps. Tübinger Geowiss. Arb., Reihe A 40168 pp.

Brügel, A., Dunkl, I., Frisch, W., Kuhlemann, J., Balogh, K., 2000. The record of Periadriatic volcanism in the Eastern Alpine Molasse zone and its paleogeographic implications. Terra Nova 12 (1), $42-47$.

Dietrich, V., 1969. Die Oberhalbsteiner Talbildung im Tertiär-ein Vergleich zwischen den Ophioliten und deren Detritus in der ostschweizerischen Molasse. Eclogae Geol. Helv. 62 (2), 637-641.

Dunkl, I., in press. TRACKKEY: a Windows program for calculation and graphical presentation of fission track data. Computers $\&$ Geosciences.

Dunkl, I., Frisch, W., Kuhlemann, J., Brügel, A., 1998. Pebblepopulation-dating: a new method for provenance analysis. Terra Nostra 98 (1), 45.

Dunk1, I., Spiegel, C., Kuhlemann, J., Frisch, W., 2000. Impact of the volcanism on age-provenance studies-the Periadriatic event in the Alpine Molasse. 9th International Conference on Fission Track Dating and Thermochronology, Lorne, Australia, Geological Society of Australia, Sydney, pp. 75-76.

Fleischer, R., Price, P., Walker, R., 1964. Fission-track ages of zircons. J. Geophys. Res. 69 (22), 4885-4888.

Flisch, M., 1986. Die Hebungsgeschichte der oberostalpinen Silvretta-Decke seit der mittleren Kreide. Bull. Ver. Schweiz. Pet.Geol. Ing. 53, 23-49.

Frank, W., Kralik, M., Scharbert, S., Thöni, M., 1987. Geochronological data from the Eastern Alps. In: Flügel, H., Faupl, P. (Eds.), Geodynamics of the Eastern Alps., Deuticke, Wien, pp. $272-281$.

Frisch, W., Kuhlemann, J., Dunkl, I., Brügel, A., 1998. Palinspastic reconstruction and topographic evolution of the Eastern Alps during late Tertiary tectonic extrusion. Tectonophysics 297 , $1-15$.

Frisch, W., Dunkl, I., Kuhlemann, J., 2000. Post-collisional largescale extension in the Eastern Alps. Tectonophysics 327, 239265.

Füchtbauer, H., 1964. Sedimentpetrographische Untersuchungen in der älteren Molasse nördlich der Alpen. Eclogae Geol. Helv. 57, 157-298.

Gelati, R., Napolitano, A., Valdisturlo, A., 1988. La Gonfolite Lombarda: Statigrafia e significato nell'evoluzione del margine sudalpino. Riv. Ital. Paleontol. Strat. 94 (2), 285-332.

Giger, M., 1991, Geochronologische und petrographische Studien an Geröllen und Sedimenten der Gonfolite Lombarda Gruppe (Südschweiz und Norditalien) und ihr Vergleich mit dem Alpinen Hinterland. PhD Thesis, Universität Bern, Switzerland.
Giger, M., Hurford, A., 1989. Tertiary intrusives of the Central Alps: their Tertiary uplift, erosion, redeposition and burial in the south-alpine foreland. Eclogae Geol. Helv. 83 (3), 857-866.

Gunzenhauser, B., 1985. Zur Sedimentologie und Paläogeographie der Oligo-Miozänen Gonfolite Lombarda zwischen Lago Maggiore und der Brianza (Südtessin Lombardei). Beitr. Geol. Karte Schweiz, 159.

Hay, W., Wold, C., Herzog, J., 1992. Preliminary mass-balanced 3-D reconstructions of the Alps and surrounding area during the Miocene. In: Flug, R., Harbaugh, J. (Eds.), Computer Graphics in Geology. Lecture Notes in Earth Sciences, vol. 41, pp. 99-110.

Hurford, A., 1986. Cooling and uplift patterns in the Lepontine Alps, South Central Switzerland and an age of vertical movement on the Insubric fault line. Contrib. Mineral. Petrol. 92, $412-427$.

Hurford, A.J., Fitch, F.J., Clarke, A., 1984. Resolution of the age structure of the detrital zircon populations of two Lower Cretaceous sandstones from the Weald of England by fission track dating. Geol. Mag. 121, 269-277.

Hurford, A., Hunziker, J., Stoeckert, B., 1991. Constraints on the late thermotectonic evolution of the Western Alps; evidence for episodic rapid uplift. Tectonics 10 (4), 758-769.

Hunziker, J., Desmons, J., Hurford, A., 1992. 32 years of geochronological work in the Central and Western Alps: a review on seven maps. Mémoires de Géologie (Lausanne), 13.

Jäger, E., 1973. Die alpine Orogenese im Lichte der radiometrischen Altersbestimmung. Eclogae Geol. Helv. 66, 11-21.

Jäger, E., Hantke, R., 1984. Evidenzen für die Vergletscherung eines alpinen Bergeller Hochgebirges an der Grenze Oligozän/Miozän. Geol. Rdsch. 73 (2), 567-575.

Jäger, E., Niggli, E., Wenk, E., 1967. Rb-Sr Altersbestimmungen an Glimmern der Zentralalpen. Beitr. Geol. Karte Schweiz, 134.

Kempf, O., 1998. Magnetostratigraphy and facies evolution of the Lower Freshwater Molasse (USM) of eastern Switzerland. PhD Thesis, Universität Bern, Switzerland.

Kempf, O., Bolliger, T., Kälin, D., Engeser, B., Matter, A., 1997. New magnetostratigraphic calibration of Early to Middle Miocene mammal biozones of the north Alpine foreland basin. In: Aguilar, J.-P., Legendre, S., Micheaux, J. (Eds.), Actes du Congrès BiochroM '97. Mém. Trav. E.P.H.E., Inst. Montpellier, France, vol. 21, pp. 547-561.

Kempf, O., Matter, A., Burbank, D., Mange, M., 1999. Depositional and structural evolution of a foreland basin margin in a magnetostratigraphic framework: the eastern Swiss molasse basin. Int. J. Earth Sci. 88, 253-275.

Kuhlemann, J., 2000. Postcollisional sediment budget of circumAlpine basins. Mem. Sci. Geol. 52 (1), 1-91.

Kuhlemann, J., Frisch, W., Dunkl, I., Székely, B., Spiegel, C., 2001. Miocene shifts of the drainage divide in the Alps and their foreland basin. Z. Geomorphol. 45 (2), 239-265.

Longo, V., 1968. Geologie und Stratigraphie des Gebietes zwischen Chiasso und Varese. PhD Thesis, ETH Zürich, Switzerland.

Mancktelow, N.S., 1985. The Simplon Line. A major displacement zone in the western Lepontine Alps. Eclogae Geol. Helv. 78, $73-96$.

Markley, M.J., Teyssier, C., Cosca, M.A., Caby, R., Hunziker, J.C., Satori, M., 1998. Alpine deformation and ${ }^{40} \mathrm{Ar} /{ }^{39} \mathrm{Ar}$ geochronol- 
ogy of synkinematic white mica in the Siviez-Mischabel nappe, western Pennine Alps, Switzerland. Tectonics 17, 407-425.

Matter, A., 1964. Sedimentologische Untersuchungen im östlichen Napfgebiet (Entlebuch, Tal der grossen Fontanne, Kt. Luzern). Eclogae Geol. Helv. 57, 315-428.

Matter, A., Weidmann, M., 1992. Tertiary sedimentation in the Swiss Molasse; an overview. Eclogae Geol. Helv. 85, 776-777.

McDougall, I., Harrison, T., 1988. Geochronology and Thermochronology by the ${ }^{40} \mathrm{Ar} /{ }^{39} \mathrm{Ar}$ Method. Oxford Univ. Press, New York.

Meyre, C., Marquer, D., Schmid, S., Ciancaleoni, L., 1998. Synorogenic extension along the Forcola Fault; correlation of Alpine deformations in the Tambo and Adula Nappes (eastern Penninic Alps). Eclogae Geol. Helv. 91 (3), 409-420.

Michalski, I., Soom, M., 1990. The Alpine thermotectonic evolution of the Aar and Gotthard massifs, central Switzerland: fission track ages on zircon and apatite and $\mathrm{K}-\mathrm{Ar}$ mica ages. Schweiz. Mineral. Petrogr. Mitt. 70, 373-387.

Pearce, J., Harris, N., Tindle, A., 1984. Trace element discrimination diagrams for the tectonic interpretation of granitic rocks. J. Petrol. 25, 956-983.

Pfiffner, O.A., 1986. Evolution of the north Alpine foreland basin in the central Alps. Int. Assoc. Sedimentol., Spec. Publ. 8, 219228.

Purdy, J., Jäger, E., $1976 .{ }^{40} \mathrm{~K}-{ }^{40} \mathrm{Ar}$ ages on rock-forming minerals from the Central Alps. Mem. 1st Geol. Mineral. Univ. Padova $30,32 \mathrm{pp}$.

Rageth, R., 1984. Intrusiva und Extrusiva der Bernina-Decke zwischen Morteratsch und Berninapass (Graubünden). Schweiz. Mineral. Petrogr. Mitt. 64, 83-109.

Ratschbacher, L., Merle, O., Davy, P., Cobbold, P., 1991. Lateral extrusion in the Eastern Alps: Part 1. Boundary conditions and experiments scaled for gravity. Tectonics 10, 245-256.

Renz, H., 1937. Zur Geologie der östlichen st. gallisch-appenzellischen Molasse. Jb. St. Gall. Natw. Ges. 69, 1-128.

Rögl, F., Cita, M., Müller, C., Hochuli, P., 1975. Biochronology of conglomerate bearing molasse sediments near Como (Italy). Riv. Ital. Paleontol. 81 (1), 57-88.

Ruffini, R., Polino, R., Callegari, E., Hunziker, J., Pfeifer, H., 1997. Volcanic clast-rich turbidites of the Tavayanne sandstones from the Thone syncline (Savoie, France): records for a tertiary postcollisional volcanism. Schweiz. Mineral. Petrogr. Mitt. 77, 161-174.

Schiemenz, S., 1960. Fazies und Paläogeographie der subalpinen Molase zwischen Bodensee und Isar. Beih. Geol. Jahrb. 38, 119 pp.

Schlunegger, F., Matter, A., Burbank, D., Klaper, E., 1997. Magnetostratigraphic constraints on relationships between evolution of the central Swiss Molasse basin and Alpine orogenic events. GSA Bull. 109, 225-241.
Schlunegger, F., Slingerland, R., Matter, A., 1998. Crustal thickening and crustal extension as controls on the evolution of the drainage network of the central Swiss Alps between $30 \mathrm{Ma}$ and the present: constraints from the stratigraphy of the North Alpine Foreland Basin and the structural evolution of the Alps. Basin Res. 10, 197-212.

Schmid, S.M., Pfiffner, O.A., Froitzheim, N., Schönborn, G., Kissling, E., 1996. Geophysical-geological transect and tectonic evolution of the Swiss-Italian Alps. Tectonics 15, 1036-1064.

Seward, D., Mancktelow, N., 1994. Neogene kinematics of the Central and Western Alps: evidence from fission track dating. Geology 22, 803-806.

Spiegel, C., Kuhlemann, J., Dunkl, I., Frisch, W., Eynatten, H.V., Kadosa, B., 2000. Erosion history of the Central Alps: evidence from zircon fission track data of the foreland basin sediments. Terra Nova 12, 163-170.

Spiegel, C., Siebel, W., Frisch, W., submitted. Sr and Nd isotope ratios of detrital epidote from molasse sediments as provenance indicator and their significance for the reconstruction of the exhumation history of the Central Alps. Chem. Geol.

Spillmann, P., Büchi, H., 1993. The pre-Alpine basement of the Lower Austroalpine nappes in the Bernina massif (Grisons, Switzerland; Valtellina, Italy). In: von Raumer, J., Neubauer, F. (Eds.), Pre-Mesozoic Geology in the Alps. Springer-Verlag, Berlin, pp. 457-467.

Steck, A., Hunziker, J., 1994. The Tertiary structural and thermal evolution of the Central Alps - compressional and extensional structures in an orogenic belt. Tectonophysics 238, 229-254.

Tanner, H., 1944. Beitrag zur Geologie der Molasse zwischen Ricken und Hörnli. Thurgau. Naturforsch. Ges. 33, 108 pp.

Thöni, M., 1981. Degree and evolution of the Alpine metamorphism in the Austroalpine unit W of the Hohe Tauern in the light of K/ $\mathrm{Ar}$ and $\mathrm{Rb} / \mathrm{Sr}$ age determinations of micas. Jahrb. Geol. Bundesanst. (Austria) 124, 111-174.

von Eynatten, H., Schlunegger, F., Gaupp, R., 1999. Exhumation of the Central Alps: evidence from ${ }^{40} \mathrm{Ar} /{ }^{39} \mathrm{Ar}$ laserprobe dating of detrital white micas from the Swiss Molasse basin. Terra Nova 11, 284-289.

Wagner, G., Reimer, M., 1972. Fission track tectonics: the tectonic interpretation of apatite fission track ages. Earth Planet. Sci. Lett. 14, 263-268.

Wagner, G., Miller, D., Jaeger, E., 1979. Fission track ages on apatite of Bergell rocks from central Alps and Bergell boulders in Oligocene sediments. Earth Planet. Sci. Lett. 45 (2), $355-$ 360.

Winkler, W., Hurford, A., von Salis Perch-Nielsen, K., Odin, G., 1990. Fission track and nannofossil ages from a Paleocene bentonite in the Schlieren Flysch (Central Alps, Switzerland). Schweiz. Mineral. Petrogr. Mitt. 70, 389-396. 